\title{
INCREASING ORGANIZATIONAL PERFORMANCE BY HUMAN RESOURCE MANAGEMENT
}

\author{
Predrag V. Ralević, Aleksandar Dragojlović, Momčilo Dobrodolac, Nebojša M. Denić, Zoran Nešić
}

Original scientific pape

Human Resource Management practices (HRM practices) are essential organizational mechanisms to generate, reinforce and sustain the action plan in every organization. The capacity of an action plan depends on the work profile of individuals and teams. This paper proposes a model of HRM practices, with the aim of increasing organizational performance through the development and maintenance over time of the work profile of individuals and teams This paper shows that by classifying the activities of the model into two blocks, the work performance of the individuals and teams can increase, which subsequently increases and sustains the organizational performance over time.

Keywords: HRM practice; performance; strategy and action plan; work profile of individuals and teams

Poboljšanje organizacijskih performansi upravljanjem ljudskim resursima

Izvorni znanstveni članak

Upravljanje ljudskim resursima u praksi (HRM prakse) je bitan organizacijski mehanizam za generiranje, jačanje i podržavanje akcijskih planova u svakoj organizaciji. Kapacitet akcijskog plana ovisi o radnom profilu pojedinaca i timova. Ovaj članak predlaže model HRM prakse, s ciljem povećanja učinkovitosti organizacije kroz razvoj i održavanje tijekom vremena radnog profila pojedinaca i timova. Ovaj rad pokazuje da klasificiranjem aktivnosti modela u dva bloka, rad i učinkovitost pojedinaca i timova mogu se povećati, čime se potom povećava i održava organizacijska uspješnost tijekom vremena.

Ključne riječi: HRM praksa; performanse; pregled radnih profila pojedinaca i timova; strategija i akcijski plan

\section{Introduction}

In each organization Human Resources (HR) consist of all human and social capital. Human resources can be a source of competitive advantage for organizations [45, 44, 63]. Authors [62] noted the importance of human resources to the organizational performance. Authors in [7] considered the impact of human resources to organizational performance. The importance and role of human resources in regard to organizational performance explicitly is presented in [53, 34, 31]. Authors in [62] argued that the knowledge, skills and abilities, behavior and training of employees are a source competitive advantage, and explicitly or implicitly have a critical role in determining the long-term performance. Insufficient consideration of human resources can lead to stagnation in the growth of competitiveness of the organization. Author in [24] argued that many organizations use only $20 \%$ capacity of human resources, which means, there is $80 \%$ of the formal potential, (cost burden on business), who are inactive or insufficiently active in the realization of strategic goals, implying that there is room for improvement of human resource management. Author in [28] argued that improving human resource management can have a positive effect to organizational performance. Human resources and human resource management (HRM) have a strategic importance because they are the potential value and they are core to generating organizational capabilities that make competitive advantage and increase performance. However, like author in [21] noted, the mechanism on how human resources impact organizational performance is not clearly understood.

Human Capital (HC) is generally defined as the Knowledge, Skills and Abilities (KSAs) individually and collectively contained in the firm's human resources [6]. The essential assumption in the studies that examine the relationship between human capital and organizational performance is that KSAs have a direct impact on organizational performance. Performance, organizational efficiency and KSAs are relatively proportional, which means increasing the level of KSAs has a positive impact on performance and organizational efficiency, and vice versa [61]. In addition, the organization can increase its performance through social capital (SC) that refers to the nature of the relationship among people internal and external to the organization [36].The assumption in the studies that examine the relationship between social capital and performance is that organizational performance affects the relationships and interactions between people, and allows organizations to achieve their priorities. Social capital has a strong positive effect on performance [60], but presently, there are no authentic and practical advices on how to create organizational capabilities based on social capital [11]. HRM practices can positively affect social capital [11]. Authors in [13] found that training of employees increases mutual confidence and cooperation. Authors in [62] presented how it can create and sustain superior performance through human and social capital. The competitive advantage and superior performance can be achieved and sustained through synergy of human and social capital. The workforce must be efficiently networked and leveraged to maximize benefits across the organization.

Many studies that explore HRM are inspired by the relationship that exists between strategy, HRM and organizational performance. More precisely, researchers believe that increased organizational performance is achieved through good HRM. There are a number of such studies and attempts to find the principles of the relationship between strategy, HRM and performance. For example, authors in the studies [47, 53, 28], explicitly define that HRM practices positively affect performance, but also note that the impact of HRM practices on the organizational performance is somewhat unclear. Previous theory and researches that examined the link 
between strategy, HRM and performance have concluded that human and social capital is a potential resource of competitive advantage. Many studies suggested that HRM practices can positively affect performance primarily through the impact on human and social capital. However, mechanism to how HRM practices impact organizational performance is not clearly understood. No one has succeeded to find the universal HRM practices that can equally be implemented in all organizations. Author in [21] sets four basic questions that have not been answered accurately, and which are necessary for HRM to make progress in the future. Questions ask what combination of HRM practices has most impacted performance and how the mere existence of the practices makes it work. Each organization is unique and requires a special set of activities that is at the moment the ideal and illusory. HRM practices and their configuration are unique, complex and dynamic in every organization because all organizations with the environment and the necessary strategies are unique, complex and dynamic. Because of the dynamic that exists in the organization and environment, defined HRM practices are changing over time. However, these HRM practices should allow the organization to dispose of and use overall human and social capital in achieving strategic goals at all times. This perspective of the relationship between strategy, HRM and performance is complex, but also, it represents more the reality of the organization.

\section{The role of HRM}

Resource BASED VIEW (RBV) is a theoretical framework that describes an adequate model relationship between strategy, HRM and performance. Because of the complexity in the relationship strategy-HRMperformance, the relationship in the literature is known as the "black box". Generally, the relationship strategyHRM-performance is shown in Fig. 1.

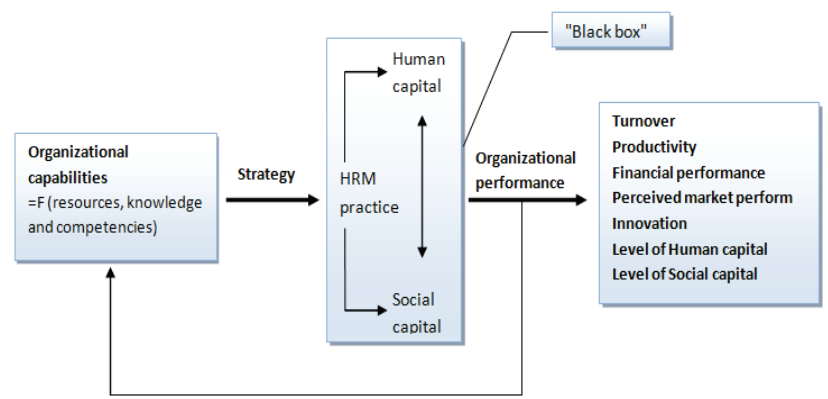

Figure 1 The relationship between strategy-HRM-performance

The problem of an adequate modeling of the relationship strategy-HRM-performance is more difficult because of the dynamics that exists in the environment that affects the organizational capabilities. Organizational capabilities develop by learning from the past, present adaptation and creation of the future based on prediction. Competitive advantage of the firm is that these capabilities necessary to create recombine and transform the organization within the context of a dynamic competitive environment. Authors in [64] concluded that this approach, even though difficult to achieve, offers the most competitive advantage because of the difficulties of copying by other companies. Manyresearches [42, 14, 25, 30] attempted to identify more specific configurations between strategy, HRM and performance, but all studies argued that seeking the final configuration is unattainable. Good point is that each configuration is unique at the moment of creation, but needs to constantly change and adapt over time.

In considering the relationship, the alignment between strategy, HRM and performance is critical $[8,56$, $22]$. These authors concluded the need to align abilities and motivation of employees with complex and dynamic strategic goals, organizational processes and results of the required work. It means that there is the need for alignment between strategy and execution, the theory is known as Line of Sight (LOS). The essential assumption of this concept is that knowledge and behavior align with strategic priorities, to achieve positive organizational performance, together with HRM practices that motivate employees in execution of strategic goals. The concept of LOS is perfect alignment between strategy, HRM and performance and represents the ideal state, which can be fully achieved only in theory. Achieving alignment is necessary, but a complex and dynamic process requires permanent monitoring and adjustment over time. In pursuit of alignment, the firm can develop resources of competitive advantage that are valuable, rare, unique and indispensable.

HRM is a mediator between strategy and performance. This role can only perform well if strategy of the firm is fully understood. The literature of strategy is focused on the core of organizational capabilities as the essential element of organizational performance [49, 44]. Strategy should be defined based on the organizational capabilities that are measured by the character of the organization to learn and to change according to the dynamics of the environment and the function of the resources, knowledge and competence with which the organization disposes. The firm's strategy is the driving force of all organizational activities, if it focuses on human resources as competitive advantage. Author in [44] argued that strategy based on reducing costs can make and sustain superior performance. Practice has shown that low-cost strategy implies competitive advantage and increase organizational performance, however permanent cost reduction based on reducing the number of employees, often results in decreasing work performance of employees because of increased workload and stress and thus the overall performance. The implementation of efficient cost control cannot be successful without the active involvement of all employees who will be motivated for this process only if there is a clear relationship between them and strategy. Authors in [42] proved that by contingent approach, strategy based on low cost, differentiation innovation and focusing in the market brings competitive advantage. When there is a clear relationship between human, social capital and business strategy, it will always imply increasing performance. Strategic management should define through strategic management process an adequate organization strategy that is continuously monitored and adjusted according to the principle of feedback over time (Fig. 1). Transparency of the strategy is the result that organizations achieve in fact. Authors in [40] in their study concluded that there is 
not an agreed methodology of measuring performance, therefore different studies examining the relationship strategy-HRM-performance are unconvincing because they analyze different levels of the organization (at the individual level, at the group level, at the organization level) and produce different performance measurements. Each of the three levels (organizational, group and individual) contributes to the overall performance [35]. Author in [28] noted that there are different aspects of performance at the organizational level such as turnover, productivity and corporate financial performance. Authors in [32] considered how productivity impacts on market share. Authors in [20] understood the results of the organization due to management characteristics of employees, innovation and relationships between employees. It means that performance at the organizational level is function of several variables such as turnover, productivity, achieved finance, market share, employee characteristics-human capital, innovation and personal relationships-social capital. There is the problem how to measure variables that are by nature intangible and cannot be measured by numbers. Authors in [5] developed a comprehensive model for measuring human capital and assessing the impact of human capital to organizational performance. These types for measuring provide complete and accurate assessment of the impact connected with the HRM strategy to performance. Performance of the group can be measured similar to that at the organizational level. Also, individual characteristics, attitudes, behavior and work performance can be measured. Authors in [21, 41] addressed the complex survey design on sophisticated statistical analysis to measure performance.

\section{$3 \quad$ HRM practices}

HRM practices have the aim to best perform the role of mediator between strategy and performance as the final results of the organization. HRM practices are focused on human resource in the organization, i.e. the development and implementation of human and social capital. Authors in [15] concluded that new HRM practices outperform the old over time and suggested that organizations need to adopt best practices because they proved that the adoption of best practices implies decreasing costs and increasing revenue. Many authors demonstrated in their studies the effect of HRM practices in creating and sustaining competitive advantage $[43,3,38,15,18,28,59]$. The researches examine the different combination of HRM practices and what the impact they have to organizational performance. For example, authors in [2] examined how activities such as recruitment, training and compensation for employees affect the organizational performance. Apart from recruitment, training and compensation, important factors that affect organizational performance are motivation and participation of employees [23, 39]. An interesting approach is the one by Tseng and Lee [57] who in their study using Data Envelopment Analysis / Analytical Hierarchical Process (DEA/AHP) demonstrated the mathematical programming that activities such as hiring, training, compensation, motivation and participation of employees have a positive impact on organizational performance [57].
Many current theoretical and empirical studies focus on HRM practices as essential resource competitive advantage. HRM practices are especially important when firms choose to grow through association or when firms seek to grow through their international cooperators where people do not belong to the culture of the parent firm [1]. HRM practices are useful to provide the creation and maintenance of other resources necessary for planning and executing the strategic priorities of the firm. Authors in [9] defined some practical propositions that consist of the requirement and sufficient condition for increasing organizational performance. They believed the requirement condition is that HRM practices generate, reinforce and sustain organizational capabilities and culture, group norms, individual KSAs and opportunities. The sufficient condition is that all those elements needed to generate, reinforce and sustain over time must be aligned with strategy. The proposed model of HRM practices in function of increasing organizational performance is shown in Fig. 2. The assumption in the model is that superior performance results from the direct relationship between strategy (strategic goals) and action plan when implemented through the work profiles of individuals and teams.

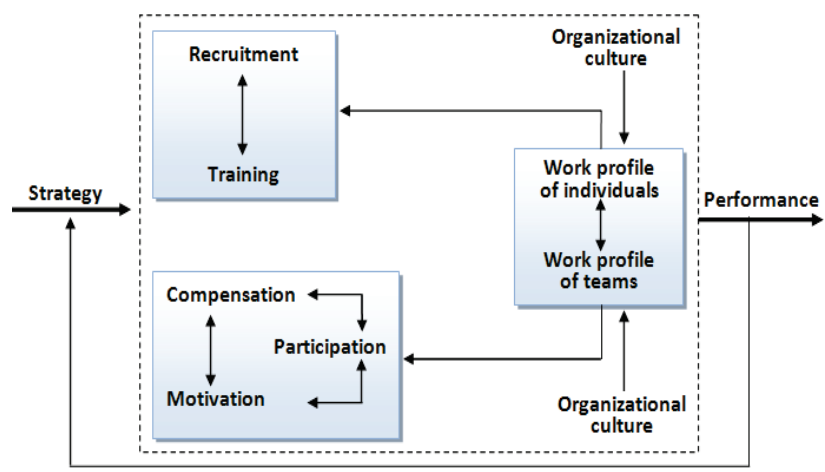

Figure 2The model of HRM practices in function of increasing organizational performance

Chronologically, the first activity of HRM is recruitment. Recruitment needs to attract and select candidates who possess necessary competencies to perform different categories of works within the organization (Fig. 2). Necessary competencies for different categories of work need to be defined in regard to strategy. Authors in [51] defined competency as the basic characteristic of an individual that is causally related with work performance or situation. Authors [35] described the competencies as configuration of knowledge, skills and abilities that allow someone to perform professionally. All employees do not possess competencies equally significant. Authors in [33] presented architecture of human resources based on strategic role of employees that consists the value and uniqueness of characteristics of employees. Employees who possess characteristics of the value and uniqueness have the greatest strategic significance. The benefit to the organization of these employees far exceeds costs required for their development, deployment and the managerial and bureaucratic costs. Employees who possess characteristics of the value or uniqueness, but not both, have less strategic significance, and those who do not possess characteristics of the value and uniqueness, do 
not have strategic significance. It can be concluded that a good organization is when all employees can contribute, achieving strategic goals and where there are no employees with less or no strategic significance. Otherwise the layering of employees in strategic significance impacts negatively on social capital. Authors in [8] concluded that if there is potential of strategic value for all activities in the organization, then organizations which achieve this state, become better places to capture this potential value. Training is an essential activity of HRM, intended to prepare individuals and work teams for daily tasks (Fig. 2). Training is a critical activity because it needs to systematize and improve the existing knowledge, skills and abilities (KSAs) of individuals and work teams. Training programs can be an important resource for preparing employees to cope with job demands. As described by author in [29] individuals are more ready and available to engage in their roles when they can cope with various demands and when they have the ability to engage in coping strategies. The result of training is the work profiles of individuals and teams. Training of individuals and teams can increase the influence of organizational culture as the common factor of integration of all employees. The organization as creator of the organizational culture must align values of employees with values of the organization [27]. When values of employees align with values of the organization then most probably employees will have a positive attitude about the organization and is less probably that employees will leave this organization [37]. Author in [48] concluded that organizational culture is the important factor for organizational performance because it shapes norms behavior of employees. Organizational culture affects the attitude and behavior of all employees (individuals and teams), and has a big impact on organizational results $[54,50,55]$. These studies showed that high work performance and highly engaging are related with positive organizational results. It means the work profiles of individuals and teams are function of knowledge, skills and abilities (systematized and improved level of KSAs by training) and organizational culture.

With the full development and utilization of the work profiles of individuals and teams, it is possible to allocate adequate compensation for achieved work performance of employees and stimulate motivation (Fig. 2). Compensation and motivation are important activities of HRM, needed to enable the organization to exploit the total potential of human resources that comprise the work profiles of individuals and teams. Compensation provides the alignment of interests between the organization and the employee based on the assessment of work performance. Employees must be responsible in executing their tasks. Each daily task of employees must be defined, communicated and measured and employees need to receive regular feedback on their work performance. Compensation must be related to work performance of employees [17]. Authors in [19] concluded that employees want to contribute in achieving the organization goals if they believe their actions are instrumental in the system of the organization. However, this focus can be problematic because there is often no clear and direct relationship between the employee and organizational results. Authors in [8] suggested that alignment of interests can be done not only by rewarding but also through the organizational culture and the work itself (if employees believe that their work is significant and contribute to the organizational goals, they will be more ready to engage in contributing to these objectives). These authors, [8], described two related elements: Action and Interest that affect the behavior of employees in regard to strategic goals. The Action of the employee is function of his/her competencies that depend on KSAs. Organizations require that competencies be used effectively and efficiently (achieved high work performance), and that employees have the opportunity to apply competencies in achieving strategic goals. This opportunity is largely a function of organizational politics.

It can be concluded that not enough of employees possess necessary knowledge, skills, and abilities to have the opportunity to contribute in achieving strategic goals. They need to possess KSAs and to have the opportunity to engage in actions that lead toward the achievement of strategic objectives (the necessary condition), but they have to also want to do such actions (the sufficient condition). Employees will have the desire if there is alignment of interests between employees and the organization. Alignment of interests is function of compensation (external rewards) and all the other benefits that employees can get away from the work (internal rewards). HRM has the key role in motivating employees in achieving of strategic objectives. Motivation can increase the desire of employees - individuals and work teams (Fig. 2) to perform the necessary actions. Motivate employees is possible if the relationship person organization (P-O) is known [10]. For example, authors in [8] found that for employees it was more important to understand how to contribute to strategic goals of the organization than only to understand those goals. They concluded that employees who understand how to contribute to strategic goals have more sense of belonging. Authors in [26] demonstrated that a higher level of $\mathrm{P}-\mathrm{O}$ can be achieved when leaders encourage their workers, colleagues to create a better person organization relationship, and enhance team work [26]. The level of P-O can be increased through goal congruence of employees and the organization. Authors in [58] demonstrated when the goals of employees aligned with goals of their immediate supervisors; employees had a more positive attitude about the organization and remained for a longer period of employment in the organization. Goal congruence contributes that employees have a better perception of their role within the organization, and have more sense significant of tasks, which results in increased work performance. Furthermore, it can be perceived positively if employees have opportunities to participate in the control systems. Authors in [4] concluded that employees who have opportunity to participate in control systems, possess necessary KSAs and incentives to do the task, they will perform the tasks better than others who do not have those attributes. The opportunity for employees to participate in decisions related to the organizational activities or work teams, contributes to increase trust between managers and employees and it increases motivation due to increased awareness of the meaning and significance of the work. 


\section{Conclusion}

HRM practices are strategically important only if they facilitate the development of human and social capital necessary to create and perform the organization strategy as driving force of all organizational activities. HRM can help the organization to develop necessary culture for creating and performing strategy. HRM practices are the essential organizational mechanisms to generate, reinforce and sustain activities of employees, and measure the performance of an action plan. It is not enough that there are HRM practices; they have to be efficiently implemented by managers and employees. HRM can increase strategic value of the organization by designing the organization and management changes. Organization design is fundamental to the creation of social capital. Efficiently management of organizational change is essential to achieving and maintaining alignment between strategy, HRM and performance.

In this paper is suggested a model of HRM practices in function of increasing organizational performance. Organizational culture takes the important place in the model, it acts on individuals and work teams and affects their work profiles. Working potential of individuals and work teams can be increased by organizational culture, only if organizational culture is a common factor in the integration of all employees. It influences the attitudes and behavior of each employee either working individually or as part of a team and therefore in the aggregate it impacts the organizational results. Otherwise, wrongly created (consciously or unconsciously by the organization) organizational culture is the disintegration factor of employees, decreasing the working potential of individuals and teams, and the overall organizational performance. Further, the main activities of the model are recruitment, training, compensation, motivation and participation that are classified according to coherence in two different blocks of activities. The first block consists of recruitment and training, the second block consists of compensation, motivation and participation. The first block, recruitment and training, is directly proportional to the activities. It means that the result of training directly depends on recruitment, accurately it is better to attract and select candidates that will be trained to perform various categories of the works within the organization. Systematization and improving existing knowledge, skills and abilities of individuals and work teams through training implies that employees perform a more professional role. In the model, the result of training is the work profiles of individuals and teams, which are continually influenced by the organizational culture. The second block, compensation, motivation and participation, is also important in the full development and utilization of human resources - work profiles of individuals and teams. Compensation as alignment of interests between the organization and employees should be related to the individual employee and the value of that employee to the organization. This alignment of interests will increase the desire and necessary actions to achieve strategic objectives. Motivation on individuals and work teams enhances the desire to do necessary actions. If employees understand how to contribute to strategic goals and if there is goal congruence between them and the organization, individuals and work teams will have the sense of belonging that enhances the performance of individuals and teams. In such an atmosphere, individuals and work teams will be better motivated, accurately they will perceive their role better, and they will have a greater sense of significance of the tasks performed, increasing performance levels. It is recommended that individuals and work teams be given the opportunity to participate in the control systems, as it increases mutual confidence and motivation because of increased awareness of the meaning and significance of work. It means, in the second block, that compensation, motivation and participation are directly dependent on each other. The best effect on work profiles of individuals and teams can be obtained if there is a synergy of these three activities. Also, it needs that work profiles of individuals and teams are monitored over time depending on the circumstances. It means that two blocks of activities have to be adopted over time and impact the work profile of individuals and teams based on perceived changes. In this way a mechanism will be established that will be a mediator between performance and strategy. This mechanism will generate and sustain superior organizational performance over time.

Superior organizational performance is the result of the direct relationship between strategic goals and the action plan. In the suggested model the action plan is function of the work profiles of individuals and teams. It is shown that work performance of individuals and teams is possible to be enhanced based on HRM practices, which increase and sustain organizational performance over time. Future research could be based on the quantification of the increase in performance by each particular HRM activity through the work profiles of individuals and teams. For example, to what extent any of the presented activities affects individuals and teams and total organizational performance. For such analysis, it is necessary to use contingent approach and comprehensive models to accurately describe and capture the complexity and dynamics of strategy and HRM. Also, in this paper, modeled activities are related to organizations that are characteristically planned, and possess a structure and processes. However, organizations are living organisms and they are influenced by various interacting factors that can lead to the unplanned and exceptional circumstances. Colbert [12] recommended that researches examine the human interactions and processes (both planned and unplanned conditions) that lead to the creation of various HRM practices, and find how these interactions and processes develop over time. As the author in [12] recommended, these and other questions should be examined using qualitative methods.

\section{References}

[1] Allred, B.; Boal, K. B.; Holstein. K. Corporations as stepfamilies: A new metaphor for explaining the fate of merged and acquired companies. // The Academy of Management Executive. 19, 3(2005), pp. 23-37. DOl: 10.5465/AME.2005.18733213

[2] Ahmad, S.; Schroeder, R. G. The impact of human resource management practices on operational performance: recognizing country and industry differences. // Journal of Operations Management. 21, 1(2003), pp. 19-43. DOI: 10.1016/S0272-6963(02)00056-6 
[3] Arthur, J. B. Effects of human resource systems on manufacturing performance and turnover. // Academy of Management Journal. 37, 3(1994), pp. 670-687. DOl: $10.2307 / 256705$

[4] Appelbaum, E.; Bailey, T.; Berg, P.; Kalleberg, A. Manufacturing advantage: Why high-performance work systems pay off. Ithaca, New York, ILR Press. 2000.

[5] Bassi, L.; McMurrer, D. Maximizing your return on people. // Harvard Business Review. 85, 3(2007), pp. 115-123.

[6] Becker, G. S. Human capital. New York, Columbia Free Press, 1964.

[7] Becker, B.; Gerhart, B. The impact of human resource management on organizational performance: Progress and Prospects. // The Academy of Management Journal. 39, 4(1996), pp. 779-801. DOI: 10.2307/256712

[8] Boswell, W. R.; Bingham, J. B.; Colvin, A. J. S. Aligning employees through "line of sight". // Business Horizons. 49, 6(2006), pp. 499-509. DOI: 10.1016/j.bushor.2006.05.001

[9] Buler, P. F. ; McEvoy, G. M. Strategy, human resource management and performance: Sharpening line of sight. // Human resource management review. 22, 1(2012), pp. 4356. DOI: 10.1016/j.hrmr.2011.11.002

[10] Chatman, J. A. Improving interactional organizational research: a model of person-organization fit. // Academy of Management Review. 14, 3(1989), pp. 333-349. DOI: $10.2307 / 258171$

[11] Chisholm, A. M.; Nielsen, K. Social capital and the resource-based view of the firm. // International Studies of Management and Organization. 39, 2(2009), pp. 7-32. DOI: 10.2753/IMO0020-8825390201

[12] Colbert, B. A. The complex resource-based view: Implications for theory and practice in strategic human resource management. // Academy of Management Review. 29, 3(2004), pp. 341-358. DOI: 10.2307/20159047

[13] Collins, C. J.; Smith, K. G. Knowledge exchange and combination: The role of human resource practices in the performance of high-technology firms. // Academy of Management Journal. 49, 3(2006), pp. 544-560. DOl: 10.5465/AMJ.2006.21794671

[14] Collins, C. J.; Clark, K. D. Strategic human resource practices, top management team social networks, and firm performance: The role of human resource practices in creating organizational competitive advantage. // Academy of Management Journal. 46, 6(2003), pp. 740-751. DOl: $10.2307 / 30040665$

[15] Delery, J.; Doty, D. Modes of theorizing in strategic human resource management: Tests of university contingency and configurational performance predictions. // Academy of Management Journal. 39, 4(1996), pp. 802-835. DOl: $10.2307 / 256713$

[16] Denison, D. R. What is the difference between culture and organizational climate? A native's point of view on a decade of paradigm wars. // Academy of Management Review. 21, 3(1996), pp. 619-654. DOI: 10.2307/258997

[17] Eisenhart, K. M. Agency theory: an assessment and review. // Academy of Management Review. 14, 1(1989), pp. 5774. DOI: $10.2307 / 258191$

[18] Fields, D.; Chan, A.; Akhtar, S. Organizational context and human resource management strategy: A structural equation analysis of Hong Kong firms. // International Journal of Human Resource Management. 11, 2(2000), pp. 264-277. DOI: $10.1080 / 095851900339864$

[19] Gerhart, B.; Milkovich, G. T. Organizational differences in managerial compensation and firm performance. // Academy of Management Journal. 33, 4(1990), pp. 663691. DOI: $10.2307 / 256286$

[20] Guest, D.; Conway, N.; Dewe, P. Using sequential tree analysis to search for bundles of HR practices. // Human Resource Management Journal. 14, 1(2004), pp. 79-96. DOI: 10.1111/j.1748-8583.2004.tb00113.x
[21] Guest, D. E. Human resource management and performance: Still searching for some answers. // Human Resource Management Journal. 21, 1(2011), pp. 3-13. DOI: 10.1111/j.1748-8583.2010.00164.x

[22] Gratton, L.; Hope-Hailey, V.; Stiles, P.; Truss, C. Linking individual performance to business strategy: The people process model. // Human Resource Management. 38, 1(1999), pp. 17-31. DOI: 10.1002/(SICl)1099050X(199921)38:1<17::AID-HRM3>3.0.CO;2-A

[23] Harel, G. H.; Tzafrir, S. D. The effect of human resource management practices on the perceptions of organizational and market performance of the firm. // Human Resource Management. 38, 3(1999), pp. 185-200. DOl: 10.1002/(SICI)1099-050X(199923)38:3<185::AIDHRM2>3.0.CO;2-Y

[24] Harington, J. Take a Look Inside. // Incentive. 177, 11(2003), pp. 16-16.

[25] Hayton, J. C. Strategic human capital management in SMEs: An empirical study of entrepreneurial performance. // Human Resource Management. 42, 4(2003), pp. 375-391. DOI: 10.1002/hrm.10096

[26] Hoffman, B. J.; Bynum, B. H.; Piccolo, R. F.; Sutton, A. W. Person-organization value congruence: How transformational leaders influence work group effectiveness. // Academy of Management Journal. 54, 4(2011), pp. 779-796. DOI: 10.5465/AMJ.2011.64870139

[27] Hodgetts, R. M.; Luthans, F. International Management, Culture, Strategy and Behavior ( $5^{\text {th }}$ edition), McGraw Hill Irwin, Boston, USA, 2003.

[28] Huselid, M. A. The impact of human resource management practices on turnover, productivity, and corporate financial performance. // Academy of Management Journal. 38, 3(1995), pp. 635-672. DOI: $10.2307 / 256741$

[29] Kahn, W. A. Psychological conditions of personal engagement and disengagement at work. // Academy of Management Journal. 33, 4(1990), pp. 692-724. DOl: $10.2307 / 256287$

[30] Kim, H.; Gong, Y. The roles of tacit knowledge and OCB in the relationship between group-based pay and firm performance. // Human Resource Management Journal. 19, 2(2009), pp. 120-139. DOI: 10.1111/j.1748-8583.2009.00093.x

[31] Kochan, T. A.; Osterman, P. The mutual gains enterprise. Boston: Harvard Business School Press, 1994.

[32] Lai, K. H.; Cheng, T. C. E. Effects of quality management and marketing on organizational performance. // Journal of Business Research. 58, 4(2005), pp. 446-456. DOI: 10.1016/j.jbusres.2003.08.001

[33] Lepak, D. P.; Snell, S. A. The human resource architecture: Toward a theory of human capital allocation and development. // Academy of Management Review. 24 1(1999), pp. 31-48. DOI: 10.2307/259035

[34] MacDuffie, J. P. Human resource bundles and manufacturing performance: Organizational logic and flexible production systems in the world auto industry. // Industrial and Labor Relations Review. 48, 2(1995), pp. 197-221. DOI: $10.2307 / 2524483$

[35] McEvoy, G. M.; Hayton, J. C.; Warnick, A. P.; Mumford, T. V.; Hanks, S. H.; Blahna, M. J. A Competency-Based Model for Developing Human Resource Professionals. // Journal of Management Education. 29, 3(2005), pp. 383402. DOI: $10.1177 / 1052562904267538$

[36] Nahapiet, J.; Ghoshall, S. Social capital, intellectual capital, and the organizational advantage. // Academy of Management Review. 23, 2(1998), pp. 242-266. DOI: $10.2307 / 259373$

[37] O'Reilly, C. A.; Chatman, J.; Caldwell, D. F. People and organizational culture: A profile comparison to assessing person-organization fit. // Academy of Management Journal. 34, 3(1991), pp. 487-516. DOI: 10.2307/256404 
[38] Osterman, P. How common is workplace transformation and who adopts it? // Industrial and Labor Relations Review. 47, 2(1994), pp. 173-188. DOI: 10.2307/2524415

[39] Paul, A. K.; Anantharaman, R. N. Impact of people management practices on organizational performance. Analysis of a casual model. // International Journal of Human Resource Management. 14, 7(2003), pp. 12461266. DOI: $10.1080 / 0958519032000145648$

[40] Paauwe, J.; Boselie, P. HRM and performance: What next? // Human Resource Management Journal. 15, 4(2005), pp. 68-83. DOI: 10.1111/j.1748-8583.2005.tb00296.x

[41] Paauwe, J. HRM and performance: Achievements, methodological issues and prospects. // Journal of Management Studies. 46, 1(2009), pp. 129-142. DOI: 10.1111/j.1467-6486.2008.00809.x

[42] Pertusa-Ortega, E. M.; Molina-Azorın, J. F.; Claver-Cortes, E. Competitive strategy, structure and firm performance: A comparison of the resource-based view the contingency approach. // Management Decision. 48, 8(2010), pp. 12821301. DOI: $10.1108 / 00251741011076799$

[43] Pfeffer, J. Seven practices of successful organizations. // California Management Review. 40, 2(1998), pp. 96-124. DOI: $10.2307 / 41165935$

[44] Porter, M. E. Competitive advantage: Creating and sustaining superior performance. New York, Free Press, 1985.

[45] Prahalad, C. K.; Hamel, G. The core competence of the corporation. // Harvard Business Review. 68, 3(1990), pp. 79-91.

[46] Prahalad, C. K. Developing strategic capability: An agenda for top management. // Human Resource Management. 22, 3(1983), pp. 237-254. DOI: 10.1002/hrm.3930220304

[47] Russell, J. S.; Terborg, J. R.; Powers, M. L. Organizational productivity and organizational level training and support. // Personnel Psychology. 38, 4(1985), pp. 849-863. DOl: 10.1111/j.1744-6570.1985.tb00570.x

[48] Schein, E. H. Organizational culture and leadership $\left(2^{\text {nd }}\right.$ edition), San Francisco CA: Jossey - Bass, 1992.

[49] Slevin, D. P.; Covin, J. G. Strategy formation patterns, performance, and the significance of context. // Journal of Management. 23, 2(1997), pp. 189-209. DOI: 10.1016/S01492063(97) $90043-X$

[50] Smith, P. B.; Peterson, M. B. Beyond value comparisons: Sources used to give meaning to management work events in thirty countries. Paper presented at the $26^{\text {th }}$ International Congres of Psychology, Montreal, Canada, 1996.

[51] Spencer, L. M.; Spencer, S. M. Competency at work: Models for superior performance. New York, John Wiley, 1993.

[52] Stalk, G.; Evans, P.; Schulman, L. Competing on capabilities: The new rules of corporate strategy. // Harvard Business Review. 70, 2(1992), pp. 57-69.

[53] Terpstra, D. E.; Rozell, E. J. The relationship of staffing practices to organizational level measures of performance. // Personnel Psychology. 46, 1(1993), pp. 27-48. DOI: 10.1111/j.1744-6570.1993.tb00866.x

[54] Triandis, H. C. Review of culture's consequences: International differences in work-related values. // Human Organization. 41, 1(1982), pp. 86-90.

[55] Trompenaars, F. Riding the waves of culture, London: Brealey, 1993.

[56] Truss, C. Complexities and controversies in linking HRM with organizational outcomes. // Journal of Management Studies. 38, 8(2001), pp. 1121-1149. DOI: 10.1111/14676486.00275

[57] Tseng, Y. F.; Lee, T. Z. Comparing appropriate decision support of human resource practices on organizational performance with DEA/AHP model. // Expert Systems with
Applications. 36, 3(2009), pp. 6548-6558. DOl: 10.1016/j.eswa.2008.07.066

[58] Vancouver, J. B.; Millsap, R. E.; Peters, P. A. Multilevel analysis of organizational goal congruence. // Journal of Applied Psychology. 79, 5(1994), pp. 666-679. DOl: 10.1037/0021-9010.79.5.666

[59] Youndt, M. A.; Snell, S. A.; Dean, J. W.; Lepak, D. P. Human resource management, manufacturing strategy and firm performance. // Academy of Management Journal. 39, 4(1996), pp. 836-866. DOI: 10.2307/256714

[60] Westlund, H.; Adam, F. Social capital and performance: A meta-analysis of 65 studies. // European Planning Studies. 18, 6(2010), pp. 893-919. DOI: 10.1080/09654311003701431

[61] Wright, P. M.; McMahan, G. C. Exploring human capital: Putting human back into strategic human resource management. // Human Resource Management Journal. 21, 2(2011), pp. 93-104. DOI: 10.1111/j.1748-8583.2010.00165.x

[62] Wright, P. M.; Dunford, B. B.; Snell, S. A. Human resources and the resource based view of the firm. // Journal of Management, 27, 6(2001), pp. 701-721. DOl: 10.1177/014920630102700607

[63] Wright, P. M.; McMahan, G. C.; Mc Williams, A. Human resources and sustained competitive advantage: A resourcebased perspective. // International Journal of Human Resources Management. 5, 2(1994), pp. 301-326. DOI: 10.1080/09585199400000020

[64] Zhou, X.; Anand, J.; Mitchell, W. Transferring collective knowledge: Teaching and learning in the Chinese auto industry. // Strategic Organization. 2, 2(2004), pp. 133-166. DOI: $10.1177 / 1476127004042842$

\section{Authors' addresses}

Predrag V. Ralević, PhD candidate

Polytechnical School of Professional Studies, University of Kosovska Mitrovica, Nušićeva 6, 38220 Kosovska Mitrovica, Serbia E-mail: ralevicpredrag@gmail.com

\section{Aleksandar Dragojlović, MSc}

The Deutsche Gesellschaftfür Internationale Zusammenarbeit (GIZ),

Kralja Milana 17/4, 11000 Belgrade, Serbia

E-mail: aleksdragojlovic@gmail.com

\section{Momčilo Dobrodolac, PhD}

Facultyof Transport and Traffic Engineering, University of Belgrade,

Vojvode Stepe 305, 11000 Belgrade, Serbia E-mail:m.dobrodolac@gmail.com

\section{Nebojša Denić, PhD}

Faculty of Information Technology,

Alfa University,

PalmiraToljatija 3, 11000 Belgrade, Serbia

E-mail: denicnebojsa@gmail.com

\section{Zoran Nešić, PhD}

Faculty of Technical Sciences Čačak University of Kragujevac

Svetog Save 65, 32000 Čačak, Serbia

E-mail: zornes2002@yahoo.com 